\title{
Board Composition and Social \& Environmental Accountability: A Dynamic Model Analysis of Chinese Firms
}

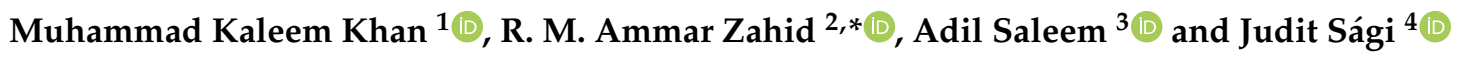 \\ 1 School of Economics and Management, East China Jiaotong University, Nanchang 330013, China; \\ mkaleemkhan@yahoo.com \\ 2 School of Economics and Finance, Xi'an Jiaotong University, Xi'an 710049, China \\ 3 Doctoral School of Economics and Regional Sciences, Hungarian University of Agriculture and Life Sciences, \\ H-2100 Gödöllő, Hungary; saleem.adil@phd.uni-szie.hu \\ 4 Faculty of Finance and Accountancy, Budapest Business School, University of Applied Sciences, \\ H-1149 Budapest, Hungary; sagi.judit@uni-bge.hu \\ * Correspondence: amrzahid@gmail.com; Tel.: +92-3214976079
}

Citation: Khan, M.K.; Zahid, R.M.A.;

Saleem, A.; Sági, J. Board

Composition and Social \&

Environmental Accountability: A Dynamic Model Analysis of Chinese Firms. Sustainability 2021, 13, 10662. https://doi.org/10.3390/su131910662

Academic Editors: Adriana Tiron-Tudor and Giuseppe Nicolò

Received: 11 August 2021

Accepted: 22 September 2021

Published: 25 September 2021

Publisher's Note: MDPI stays neutral with regard to jurisdictional claims in published maps and institutional affiliations.

Copyright: () 2021 by the authors. Licensee MDPI, Basel, Switzerland. This article is an open access article distributed under the terms and conditions of the Creative Commons Attribution (CC BY) license (https:// creativecommons.org/licenses/by/ $4.0 /)$

\begin{abstract}
This research contributes to the existing corporate governance (CG) and social and environmental accountability (SEA) literature by exploring the impact of CG mechanisms (board independence, board size, CEO duality, and board gender diversity) on Chinese firms' environmental performance, sustainability performance, and environmental information disclosures (EID). Furthermore, the investigation consequently ascertains the amount to which the CG-SEA connection is influenced by CEO qualities. Using a dynamic model of a SysGMM regression model, we found that board size, independence, and gender diversity in board and CEO duality are all favorably connected to Chinese enterprises' environmental performance over a window of 10 years (2010-2019). Additionally, our findings imply that the analyzed CEO characteristics positively moderate the relationship between CG and SEA. Our findings have significant consequences for all stakeholders, including environmentalists, corporate regulators, CEOs, policymakers, and regulators.
\end{abstract}

Keywords: corporate governance; board composition; CEO duality; environmental performance; sustainability performance; environmental information disclosures

\section{Introduction}

Whether a firm perceives itself as accountable or not depends on how it is led and controlled. Corporate governance (CG) is vitally crucial for adopting ethical conduct in an organization's entire structure and its relationships with all stakeholders. Recently, the demand for corporate accountability, especially regarding environmental and sustainability performance, has been raised because of massive industrialization, dwindling resources, damaged ecosystems, and exploited labor. The United Nations has also shown serious concern for global environmental and sustainable issues and has developed 17 global sustainable development goals (SDGs) comprising 169 targets. Sustainable development basically comprises economic, social, and environmental aspects. Griggs et al. [1] redefined it as "the development that meets current needs while safeguarding the earth's life-support system, upon which the welfare of current and future generations is contingent."

Corporate governance (CG) acts as a key determinant of corporate environmental and sustainable accountability (SEA), and we could find scant literature highlighting their theoretical relationship [2]. Nevertheless, this literature is subject to certain shortcomings; more work is required to account for the empirical link, especially in emerging markets, as research so far has yielded mixed results [2,3]. We examined the effective CG mechanisms that make firms accountable on environmental and social grounds. In particular, we determined the impact of board compositional characteristics, including board size, board independence, board gender diversity, and CEO duality, on social and environmental 
accountability. The duty to account for the actions for which an entity is held accountable is defined as accountability [4]. The nature of the accountability relationship and the associated rights to information are contextually decided by society, manifested most visibly in legislative statutes and norms established by statutory organizations [5]. To ascertain the extent of SEA, we employed the firm-level information of sustainability performance, environmental performance, and environmental information disclosure (EID) of listed Chinese firms. Moreover, we analyzed whether various CEO-related attributes (CEO gender) affect the relationship of the CG-SEA nexus. Our study drew insight from agency theory and stakeholder theory.

We concentrated on China since the globe has recently seen a remarkable change toward environmental challenges and laws in China, partly due to the negative environmental consequences of the country's phenomenal economic expansion. Increasing environmental deterioration has been connected to the economy's growth by business strategists and intellectuals [6]. This concerning scenario in China has prompted us to investigate corporate-level SEA. Environmental organizations in China began emphasizing the terms "harmonious society" and "greener GDP" in the mid-2000s due to the worsening environmental conditions and climate change $[7,8]$. Chinese firms were encouraged to implement environmentally friendly practices capable of reversing the deteriorating environmental conditions. The Chinese government formed the Environmental Protection Law and State Environmental Protection Administration agencies, while other entities set about developing the Global Reporting Initiative, designed to improve environmental reporting [9]. Furthermore, China accepted the Paris Climate Agreement to demonstrate its pledge to improve China's poor environmental position, as well as the worldwide situation in September 2016. Despite these efforts, SEA in China lags behind developed countries, probably because of weak CG in Chinese firms [10,11].

Although a massive stream of research has tried to explore different issues of CG and accountability, very few have tried to link one with other. CG research in finance is mainly governed by profitability and value maximization; very few researchers have tried to study their impact on SEA (e.g., [2,12]. CG mechanisms, especially internal governance structures, play a significant role in fostering commitment to environmentally friendly activities. Board structure and composition are important elements of the CG mechanism and a number of studies have tried to analyze the effect of board composition variables on sustainability performance in the Chinese corporate sector [13-15]. However, either these studies have not explored all major board compositions (board independence, board structure, board gender diversity, CEO duality) as the present study has done, or have not incorporated the more than one aspect of accountability. Our study fills this gap by presenting multifaceted SEA with different aspects of board composition. The evidence for the effect of CG on SEA is even scarcer in the research, using various issues related to CEO attributes and functions as moderators. Our study fills this gap, too. In sum, this study adds value in the literature by merging the insights of agency theory and stakeholder theory.

From the Chinese perspective, a number of studies has examined the country's environmental performance in a single dimension. For example, a few researchers have examined environmental performance [16,17], sustainability [18,19], and environmental information disclosure indexes $[9,20]$ for China. They have also left out other important components of accountability while studying just one. A recent investigation on Chinese data [17] examined different sustainability attributes with CEO characteristics, but it ignored EID, whereas another [16] did not include both sustainability performance and EID. To the best of our knowledge, no other study has paired multiple CG mechanisms with various accountability features while integrating various $\mathrm{CEO}$ characteristics as moderators. Therefore, we add to the literature by having developed a multi-faceted metric that encompasses all conceivable aspects of SEA, including (a) sustainable performance, (b) environmental performance, and (c) environmental information disclosure. This study will aid in assessing the overall effectiveness of China's institutionally driven sustainable development/environmental policies and regulations. 
The current study adds to the existing literature in the following unique ways. First, it evaluates the effect of board compositional characteristics on various accountability-related outcomes, such as environmental performance, sustainability performance, and disclosures. In this analysis, the board size, independence, gender diversity, and CEO duality are major drivers. Based on agency theory, our findings indicate that the compositional qualities of boards are crucial for the determination of the SEA of Chinese companies. In general, our findings indicate that all four critical board compositional characteristics are significantly connected to accountability performance. The average board size in Chinese enterprises is eight to nine members. Both board size and independence of the board in Chinese companies had a substantial positive relationship with environmental, sustainability, and EID performance. Further gender diversity on boards also affected the environmental and sustainability performance and EID. CEO duality and sustainability were significantly detrimental. However, there was no substantial link between environmental and CEO dualism and EID. Third, this was the first study to investigate the specific relationship between China's predominant corporate governance structures and business responsibility while considering the mediating functions of CEO attributes. Moreover, this was one of the first studies to analyze Chinese enterprises' sustainable and environmental performance using a dynamic model based on recent and complete panel data. Our results are not prone to endogeneity criticism because we used a dynamic model and a system generalized method of moments (SysGMM) technique. Additionally, our study can be utilized to bolster firms sustainable performance.

The study possesses very strong implications for regulators. The findings may help them reach the most effective CG mechanism to make firms accountable. Moreover, the findings will guide which kind of CEO attribute should collaborate with a particular corporate governance mechanism to make firms accountable to society. These directions will help the Chinese economy to attain a greener GDP. It has been advised that firms develop their corporate governance processes to encourage accountability, such as strengthening board gender diversity and independence, maintaining an appropriate board size, and introducing sustainability reporting.

Section 2 discusses the theoretical foundation and related literature in detail. Data and research model details are in Section 3, followed by a discussion of the results and conclusions in Sections 4 and 5, respectively.

\section{Theoretical Discussions and Hypothesis Development}

In the 21st century, corporate accountability has gained great prominence. Furthermore, concentration has diverted from the conventional profit orientation perspective to social, cultural, and environmental levels [21]. Corporations strengthen accountability to achieve the varied expectations of their stakeholders, which is why they succeed. When a corporation talks to its stakeholders about its financial, social, and environmental initiatives, it educates, informs, and changes perceptions and prospects [22]. Sustainable efforts tell more about a business's brand and identity [3].

The literature presents the different theories to explain the accountability concept, but no single theory can adequately explain it fully [23]. The current study took insight from agency theory [24] and stakeholder theory [25] to explain the governance and accountability nexus. Stakeholder theory [26] strengthens a company's connection with its stakeholders [27]. Freeman (1984) supported the engagement of top management in CSR and mentioned that corporations can use CSR to resolve conflicts among stakeholders such as managers, shareholders, employees, and customers [25]. The notion of stakeholders encourages us to think about the methods by which a corporation achieves societal legitimacy. Accountability is an important part of stakeholder relationships in normative stakeholder theory. That is, the firm and its managers are accountable not just to shareholders, but also to stakeholders. All stakeholders have a right to information about how this accountability is being discharged. CSR, from this perspective, is the responsibility of organizations rather than being demand-driven. Practically, a more managerial focus should be embraced by 
the researchers to explain the activities of corporate management. This is associated with different ethical justifications. Information, including information about social and environmental performance, which is provided to stakeholders, can represent a powerful tool. This tool is used by an organization to control, manage, influence, or even manipulate various stakeholders. "Information-including financial accounting and social accounting-is a major element that can be deployed by the organization to manage (or manipulate) the stakeholder to gain their support and approval (or to distract their opposition and disapproval)" [28]. Based on stakeholder theory, the top executives have incentives to make CSR investments to meet stakeholders' comforts. Senior managers must be responsible for stakeholders, together with shareholders. In decision-making, executives need to consider CSR, such as environmental protection, product quality, relationships with employees, and community.

Agency theory explains the relationship between CG and accountability [2]. According to agency theory, managers' private interests may influence their accountability and reporting. In this scenario, the board of directors is an important CSR instrument [29]. Firm-level accountability results from the board's decisions [30]. The board of directors looks out for all stakeholders, not just stockholders [25]. Socially and environmentally responsible firms have a broader purpose than just shareholder wealth creation [31]. There must be a push for board members to press management on CSR. This means that boards help firms behave in the best interests of all stakeholders [32]. Management should attempt to guarantee that selections are in the best interests of shareholders. Therefore, manager's opportunism' is being regulated by the board of directors [33]. By utilizing agency theory [24], researchers have argued that top management and the board get themselves involved in CSR activities to build their personal reputation [34], to generate support from society and environmentalists [35], to signal product quality [36], and to maximize goal congruence between management and other stakeholders [37-40].

\subsection{Board Composition and Accountability}

In the current era, organizations are expected to be accountable and they need to provide accounts demonstrating that they are good corporate citizens and possess the intangible assets required for future good financial performance [41]. Social and environmental accountability (EA) means that "one is responsible for one's own actions and the consequences of those actions that affect the natural environment and wider society" [42]. Accountability is more related to social legitimation than economic legitimation, and is "more closely related to public pressure variables than economic ones" [43]. By engaging in the presentation of information by means of bias and selectivity, organizations compromise transparency about their social and environmental impacts and perpetuate a myth of accountability [44].

The function of the board of directors in corporate responsibility is crucial. It is expected that effective boards will serve and cater to the requirements of all stakeholders, regardless of their composition [29]. Board directors supervise firms' connections with stakeholders, create the social agenda for the firms, contribute significant information, and formulate strategy. Many entities (regulators and significant stakeholders) have pushed firms to be more responsible, which has raised the value of good community relations and sustainable development plans [45]. Companies with successful boards are expected to support and facilitate sustainable engagement and disclosure to achieve long-term commercial success [46]. Empirical studies have documented that well-structured boards are capable of helping organizations create value and long-term strategic advantage by serving as sources of stakeholder interactions and company understanding [47]. Furthermore, board members have been more welcoming of investment in and reporting on sustainable development strategies to foster public participation [48,49].

To strengthen the board's power to influence and report on stakeholder acceptance, sustainable development initiatives are meant to assist enterprises in achieving sustainable competitive advantage. The board of directors serves as a defense mechanism for investors, 
and effective boards must consider the many stakeholder groups and their surrounding areas. Different characteristics of board structure may affect the reporting and accountability decisions.

\subsection{Board Independence}

Board independence is essential to corporate governance, serving as a check and balance on management and protecting the interests of shareholders [50]. According to agency theory, independent director boards have more monitoring and control over management [12]. Independence and clarity around CSR issues are in the agency's best interests [51]. Furthermore, according to stakeholder theory, independent directors attempt to meet social demands, causing businesses to invest more in sustainability [52].

There are different conclusions about the association between accountability and independent directors. Independent directors demonstrate great awareness of social and environmental issues and present themselves as liable to solve those issues [53]. The other members are internally focused on making money and less concerned with advertising the company's social and environmental responsibility. Independent boards help foster transparency, meaning independent directors support and encourage participation in long-term and profitable social initiatives $[12,51,53]$. Firms can give higher-quality information and better openness in their reporting to stakeholders with improved board independence [54]. Independent directors are also connected to better environmental and social performance [55]. An increase in the number of independent directors on a board increases the accountability [56,57], which results in long-term performance goals [53]. The presence of independent directors with significant seats on the board reduces the risk of conflicts of interest and helps to engage external stakeholders [58]. It is vital to monitor and regulate sustainable development challenges with board independence. Independence is likely to lead to new perspectives on environmental and social issues [59]. Following these arguments, we hypothesize a positive association between board independence and environmental and sustainability performance and EID.

Hypotheses 1. Board independence is positively associated with SEA.

\subsection{Board Gender Diversity}

Women's personal and professional aspirations and ethical standards differ from men's $[60,61]$. Empirically, women are more sensitive and cooperative than men, and they are better equipped to appraise a company's social and environmental concerns [62]. The stakeholder theory holds that when firms choose women for their board of directors, society may perceive that the company is more concerned with sustainability and environmental issues, as women are thought to be more accountable due to having more optimism than male counterparts [63]. Harjoto et al. [64] demonstrated that board gender diversity is consistent with stakeholder theory.

The corporations with a higher number of women on the board possess more accountability, as they demonstrate more disclosure [60]. As a result, the quality of decisions is improved due to independent perspectives [65]. Increasing the number of female directors improves the quality of board debate and decision-making. Women on boards generally ensure demographic diversity and reflect the socioeconomic environment's variety, promoting better knowledge of the corporate environment [66]. Female board membership and its effects on CSR disclosure are less explored, especially in developing markets [30]. However, some available studies have shown that board gender diversity correlates with sustainability [67] in emerging markets such as China, India, Indonesia, Korea, Malaysia, and Thailand. Most sample companies had just one or two women on their boards, which indicates that men prefer to rule and women are a minority without influence in CSR or other issues [68]. Firms with a bigger percentage of female directors had enhanced sustainability performance and an increased number of assurance reports to go along with such disclosure [69,70]. Contrarily, Muttakin et al. [71] found a negative relationship 
between the number of women on boards of directors and sustainability for Bangladeshi companies.

Women are more concerned about social and environmental issues than men, making them less likely to sacrifice their quality of life for financial gain [72]. In terms of communication ability, personality, dedication, diligence, and being less self-interested, women differ from men on boards of directors [73]. Therefore, women's presence on the board of directors is likely to affect a company's social and environmental profile [72]. As a result, it is envisaged that female-dominated boards will better respond to and report on a company's social and environmental responsibilities.

Hypotheses 2. The presence of female directors on the board is positively associated with SEA.

\subsection{Board Size}

Boards with fewer directors benefit from better communication and cooperation, resulting in better management monitoring and control [74,75]. Contrary to this, boards with a small number of directors may face increased workloads and duties, impairing their monitoring function [76]. Additionally, due to a lack of diverse expertise and backgrounds, the quality of advice and control supplied by tiny boards may be compromised [77]. Moreover, the size of the board of directors reflects the complexity of the business [78,79]. Given the scale and complexity of the Chinese market and companies, it is expected that larger boards will be more effective in influencing firms' sustainability and environmental performance (in terms of work allocation and responsibility distribution).

Hypotheses 3. Board size is positively associated with SEA.

\subsection{CEO Duality}

The CEO duality concept (i.e., merging the chairman of the board and the CEO of the firm) has been a source of contention among corporate governance specialists for the last couple of decades. Agency theory dictates that CEOs' private interests are likely to influence their participation in and disclosure of CSR initiatives. CEO duality could be considered a technique for exercising management authority. It lessens the board's and management's essential independence, resulting in a detrimental influence on performance [80], and fosters sustainability to please powerful stakeholders and decrease oversight or improve tenure and compensation [12]. Dualism enables more focused and adaptive leadership, which improves organizational effectiveness in a potentially unpredictable corporate environment [81]. On the other hand, the board's impartiality as a monitoring body is harmed by the CEO duality, as the chairman can set the agenda, choose members, and keep crucial information hidden from other board members [78]. CEO dualism is thought to have a negative impact on monitoring, according to past studies [82]. According to certain studies, voluntary disclosure is lower when there is CEO duality $[56,57]$.

Previous research on the link between CEO duality and accountability was inconclusive. Dias et al. [83] found a positive link between CEO dualism and sustainability performance. Contrarily, Gul and Leung [84] found that CEO duality reduces total accountability and hence makes firms less transparent, not only for shareholders but also for all stakeholders. From the perspective of developing markets, a positive relationship was found for Saudi Arabia [85], whereas no association between CEO duality and voluntary disclosure was discovered in others like Bangladesh, Malaysia, Singapore, and Hongkong [86-89].

Based on the above discussion, and keeping in mind the Chinese corporate world where CEOs usually use their powers to drive the firms as per the directions given by the Communist Party, we hypothesize a positive relationship between CEO duality and environmental and sustainability performance EID.

Hypotheses 4. CEO duality is positively associated with SEA. 


\section{Data and Methodology}

The purpose of the current study was to analyze the association between board compositional characteristics (i.e., board size, independence, gender diversity, and CEO duality) on various accountability-related outcomes, such as environmental performance, sustainability performance, and environmental sustainability disclosures.

\subsection{Data and Sample}

For this purpose, data from 4132 A share-issuing non-financial firms listed on the Shanghai and Shenzhen stock exchanges from 2010 to 2019 were analyzed. The dataset was mainly downloaded from China Stock Market \& Accounting Research (CSMAR). Furthermore, financial firms were removed from the dataset, and the variables of continuous observations were arranged with a $1 \%$ tail to minimize potential outlier issues.

One of the primary challenges when examining Chinese firms' accountability is the cross-sectional environmental and sustainability data [18]. However, a longitudinal data examination of organizations' environmental initiatives can provide a complete picture $[72,90]$. By combining longitudinal and time-series data simultaneously, this study enabled us to make more informed conclusions. This research examined the CG mechanism in a dynamic framework. It considered probable correlations between accountability, performance, current governance traits, and other business-specific variables. To be more precise, we used SysGMM to estimate relationships in a dynamic model. Because SysGMM relies on lagged values of both dependent and explanatory variables, we eliminated firms with three consecutive years of missing values. The final sample consisted of an unbalanced panel of 3052 firms, constituting 20,651 firm-year observations, ranging from 1373 in 2010 to 2649 in 2018 (lowest to highest).

\subsection{Dynamic Research Model}

The following dynamic model describing the BC-SEA relationship for firm $i$ in period $t$ was used:

$$
S E A_{i t}=B C_{i t} \beta_{B C}+C_{i t} \beta_{C}+Z_{i t} \beta_{Z}+X_{i t} \partial+\rho S E A_{i(t-1)}+\varsigma_{i}+\epsilon_{i t}
$$

where $S E A$ is firm social and environmental accountability, represented by environmental performance, sustainability performance, and environmental information disclosure (EID), alternatively; $B C$ is a vector of board composition used as corporate governance mechanisms that include board independence, board size, board gender diversity, and $\mathrm{CEO}$ duality; $\mathrm{C}$ is a vector of control variables that includes $C E O$-related control variables like CEO gender, and retiring CEO, as well as other governance- and firm-related variables; and $X$ is a vector of firm-related control variables that may affect the managerial decision regarding SEA like firm size, return on assets, and leverage ratio. The pairwise interactions between elements of the $B C$ and $C$ vectors are shown by the $Z$ vector. $\beta B C, \beta C, \beta Z$, and $\alpha$ are conformable parameter vectors; ci represents unobservable firm heterogeneity; $\varepsilon_{\text {it }}$ is the idiosyncratic error term; and the subscripts $i$ and $t$ indicate firm and year, respectively. For ease of exposition, we presumed an AR (1) process in firm performance with first order correlation $\rho$.

Complications in estimating Equation (1) could arise since current levels of the explanatory variables may be linked to the unobserved firm heterogeneity factor ci and may depend on past sea level (dynamic endogeneity). As a result, traditional pooled OLS and panel fixed-effects estimators are skewed and inconsistent. The system generalized method of moments (SysGMM) accounts for both dynamic endogeneity and unobserved heterogeneity in panel data models [91,92]. A stacked system of level and first difference equations is estimated using the SysGMM estimator. The system can be written as follows, in our case:

$$
\begin{aligned}
S E A_{i t}=B C_{i t} \beta_{B C} & +C_{i t} \beta_{C}+Z_{i t} \beta_{Z}+X_{i t} \partial+\rho S E A_{i t-1}+\varsigma_{i}+\epsilon_{i t} \Delta S E A_{i t} \Delta B C_{i t} \beta_{B C}+\Delta C_{i t} \beta_{C}+Z_{I i t} \beta_{Z}+\Delta X_{i t} \partial \\
& +\rho \Delta S E A_{i(t-1)}+\Delta S E A_{i t}+\epsilon_{i t}
\end{aligned}
$$


Model (2) assumes that including the one period lag of performance is sufficient for dynamic completeness for the sake of exposition. Instruments are thus ideal candidates for lags greater than one. The level and first difference equations' instrument sets are:

$$
\begin{gathered}
\left(\Delta B C_{i(t-2)}, \ldots, \Delta B C_{i[t-(t-2)]}, \Delta C_{i(t-2)}, \ldots, \Delta C_{i[t-(t-2)]}, \Delta Z_{i(t-2)}, \ldots, \Delta Z_{i[t-(t-2)]}, \Delta X_{i(t-2)}, \ldots, \Delta X_{i[t-(t-2)]}\right) . \\
\quad \text { and } \\
\left(C G_{i(t-2)}, \ldots, C G_{i[t-(t-2)]}, C E O_{i(t-2)}, \ldots, C E O_{i[t-(t-2)]}, Z_{i(t-2)}, \ldots, Z_{i[t-(t-2)]}, X_{i[t-(t-2)]}\right),
\end{gathered}
$$

respectively.

The initial difference formulation in Equation (2) results in significant data losses in the case of unbalanced panels with sample gaps. $\triangle S E A i t$ and subsequently $\triangle S E A i(t+1)$ will be missing if SEAit is missing. Arellano and Bover (1995) developed the forward orthogonal deviations alternative to the first difference equations in response to the sample gaps and data loss problem [91]. The orthogonal deviations technique subtracts the average of all possible future values of the variable from the contemporaneous value for each of the variables, rather than the one period lag. Only the latest observation is lost, regardless of the number of gaps. The lags can still be used as instruments because the forward deviations have no delay.

Before going any further, it is worth mentioning the benefits of SysGMM estimation. SysGMM contains firm fixed effects to account for unobservable firm heterogeneity, unlike typical pooled OLS estimation. The technique, on the other hand, goes beyond the typical fixed-effects model by allowing historical levels of firm performance to influence current values of $B C, C, Z$, and $X$. SysGMM is also robust to firm-specific heteroscedasticity and serial correlation patterns, as well as sample gaps in unbalanced panels. For endogeneity issues, it is appropriate to utilize a set of "internal" instruments, i.e., lagged values and changes in $B C, C, Z, X$, and accountability. This eliminates the requirement to obtain suitable external instruments.

\subsection{Variables Definitions and Measurement \\ 3.3.1. Dependent Variables}

We used three distinct measures of sustainability as the proxy of SEA. We used two variables, (a) "Sus_Perf" and (b) "Env_Perf," as measures of the quality rating scores of "sustainable performance" and "environmental performance," respectively. Sus_Perf and Env_Perf are assessed by independent rating agencies (e.g., HEXUN-RKS). Sustainable performance refers to a company's overall sustainable, social, and environmental performance as measured by its participation in sustainable and environmentally friendly activities over the course of a year. The amount to which a company engages in only environmentally friendly procedures and activities over the course of a year is referred to as environmental performance. These are continuous variables that range from 0 to 100 (lowest to highest rating score) and were extracted from the HEXUN database.

The data about the third variable, environmental information disclosures (EID) were manually collected from firms' annual, semiannual, and CSR reports. This measure captured the involvement of each firm in corporate-level EID [93]. Ten activities of Chinese firms relating to environment were taken based on the concept model [94] in Figure 1 and Table 1. They summarized it into two categories: environmental financial (quantitative) and non-financial (qualitative) information. These two categories include 10 components. When the firm disclosed any general qualitative information, point 1, point 2 for specific environmental information, and point 3 were assigned for quantitative information. When firms disclosed no environmental information, then 0 was given. Using monetary- and nonmonetary-related environmental disclosure is an effective tool to gauge levels of corporate EID [95]. Each firm received a score for evaluating its level of EID based on Equation (3).

$$
S E I D_{i}=\sum_{j=1}^{n} S C I D_{i}
$$


where $S E I D_{i}$ is the total score of EID for the firm $i$, and $S C I D_{i}$ is the score of the $j$ th component for the firm $i$, in which $j=1,2, \ldots, 10$.

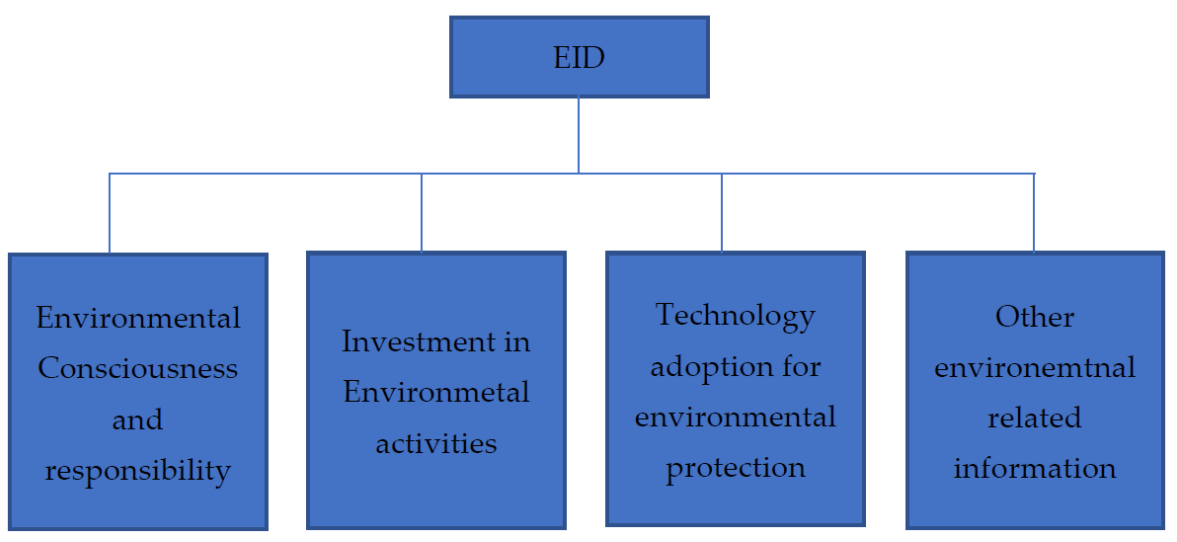

Figure 1. Environmental information disclosures (EID) components.

Table 1. Activities contributing to EID measurement.

\begin{tabular}{|c|c|c|}
\hline Activity & Definition & EID-Related Central Aspect \\
\hline $\mathrm{A}_{1}$ & $\begin{array}{l}\text { Firm's environmental investment expenditure for } \\
\text { technology development }\end{array}$ & Investment \\
\hline $\mathrm{A}_{2}$ & $\begin{array}{l}\text { Government-appropriate funds, finance allowance, and } \\
\text { taxes abatement related to the environment }\end{array}$ & Investment \\
\hline $\mathrm{A}_{3}$ & $\begin{array}{l}\text { Disposal and treatment of generated waste, recycling, and } \\
\text { integrated utilization of waste products }\end{array}$ & Technology \\
\hline $\mathrm{A}_{4}$ & $\begin{array}{l}\text { Information related to ISO environmental system } \\
\text { authentication }\end{array}$ & Consciousness and responsibility \\
\hline $\mathrm{A}_{5}$ & $\begin{array}{l}\text { Construction and operation of environmental } \\
\text { improvement }\end{array}$ & Technology \\
\hline $\mathrm{A}_{6}$ & Influence of government environmental protection policy & Consciousness and responsibility \\
\hline $\mathrm{A}_{7}$ & Loans related to environmental protection & Investment \\
\hline $\mathrm{A}_{8}$ & $\begin{array}{c}\text { Lawsuit, atonement, penalty, and bounty related to } \\
\text { environmental protection }\end{array}$ & Consciousness and responsibility \\
\hline $\mathrm{A}_{9}$ & $\begin{array}{l}\text { Firm's environmental protection policies, strategies, } \\
\text { and goals }\end{array}$ & Consciousness and responsibility \\
\hline $\mathrm{A}_{10}$ & $\begin{array}{l}\text { Other environmental-related information (environmental } \\
\text { education, tree planting, biodiversity conservation, and } \\
\text { other environmental projects to promote public welfare }\end{array}$ & Others \\
\hline
\end{tabular}

\subsubsection{Independent Variables}

Our independent variable was corporate board composition, which represents the corporate governance mechanism. The study took four independent variables, including board size (number of sitting individuals on BoD), board independence (the proportion of board members who were independent directors), board gender diversity (the proportion of board members who were female), and CEO duality (and a dummy variable equal to 1 if the CEO also served as board chair).

\subsubsection{Control Variables}

Based on prior studies [17], we used a set of control variables to account for other CG mechanism effects and firm-related factors. The board-related control variable was the number of board meetings in a year. CEO-related control variables were CEO gender 
(a dummy variable equal to 0 if the CEO was female) and retiring CEO (a dummy variable equal to 1 if the $\mathrm{CEO}$ was going to retired in a given year). Firm-level control variables were return on assets, debt-to-assets ratio, and firm size (natural log of total assets).

\section{Results and Discussion}

The descriptive statistics show that the average sustainability performance, environmental performance, and EID scores for Chinese firms were 23.331, 1.391, and 0.046, respectively. These poor average ratings and lack of environmental disclosure show that Chinese companies are still lagging in terms of implementing sustainable and environmental policies. Nonetheless, these poor average sustainable and environmental performance scores, as well as the low proportion of environmental reporting, are in accordance with prior research in China $[16,17,19]$. Moreover, Chinese firms had around eight to nine individuals on the BoD and they held around nine meetings a year. The descriptive statistics for the control variables were similarly consistent with previous studies $[16,19]$, although we have chosen not to address them in detail due to length. Appendix A has the detailed summary statistics (Table A1).

The process that underpins the dynamic findings provided below is detailed here in the spirit of transparency. First, a strict exogeneity test, as described by Wooldridge [96], was performed in panels with $\mathrm{T}>2$. Briefly, the following equation was specified:

$$
S E A_{i t}=B C_{i t} \beta_{B C}+C_{i t} \beta_{C}+Z_{i t} \beta_{Z}+X_{i t} \partial+W_{i(t-1)} \delta+\varsigma_{i}+\epsilon_{i t}
$$

where $W_{i(t-1)}$ is a vector containing the one-period lead values of $\mathrm{BC}$ and the elements of the $C, Z$, and $X$ vectors (or of a subset thereof). Strict exogeneity of any $W_{i}$ requires that $\delta_{i}=0$ and can be tested by estimating Equation (3) using standard fixed effects with robust and clustered standard errors. Industry and year dummies were included as well. Estimates of the $\delta_{i}$ s for each of the three performance equations are reported in Table 2.

Table 2. Strict exogeneity tests.

\begin{tabular}{|c|c|c|c|}
\hline Variables & Environmental Performance & Sustainable Performance & $\begin{array}{c}\text { Environmental Information } \\
\text { Disclosure (EID) }\end{array}$ \\
\hline Board Size $(t+1)$ & $\begin{array}{l}0.159 * * \\
(0.0727)\end{array}$ & $\begin{array}{l}0.760^{* * *} \\
(0.214)\end{array}$ & $\begin{array}{l}0.00530 * * \\
(0.00242)\end{array}$ \\
\hline Board Independence $(t+1)$ & $\begin{array}{c}0.761 \\
(1.790)\end{array}$ & $\begin{array}{c}5.069 \\
(5.199)\end{array}$ & $\begin{array}{c}0.0254 \\
(0.0597)\end{array}$ \\
\hline Board Gender Diversity $(t+1)$ & $\begin{array}{l}-3.041 * * * \\
(0.762)\end{array}$ & $\begin{array}{l}-10.09 * * * \\
(2.389)\end{array}$ & $\begin{array}{l}-0.101^{* * *} \\
(0.0254)\end{array}$ \\
\hline CEO Duality $(t+1)$ & $\begin{array}{l}-0.167 \\
(0.156)\end{array}$ & $\begin{array}{l}-0.391 \\
(0.479)\end{array}$ & $\begin{array}{l}-0.00556 \\
(0.00521)\end{array}$ \\
\hline Board Meetings $(t+1)$ & $\begin{array}{c}-0.0244 * \\
(0.0135)\end{array}$ & $\begin{array}{l}-0.142 * * * \\
(0.0424)\end{array}$ & $\begin{array}{l}-0.000813 * \\
(0.000449)\end{array}$ \\
\hline CEO Gender $(t+1)$ & $\begin{array}{l}-0.0590 \\
(0.328)\end{array}$ & $\begin{array}{l}-0.407 \\
(0.940)\end{array}$ & $\begin{array}{c}-0.00197 \\
(0.0109)\end{array}$ \\
\hline CEO Retiring $(t+1)$ & $\begin{array}{l}-0.331 \\
(0.287)\end{array}$ & $\begin{array}{l}-0.732 \\
(0.948)\end{array}$ & $\begin{array}{c}-0.0110 \\
(0.00955)\end{array}$ \\
\hline Debt to Assets $(t+1)$ & $\begin{array}{c}0.706 \\
(0.429)\end{array}$ & $\begin{array}{l}-6.097^{* * *} \\
(1.417)\end{array}$ & $\begin{array}{c}0.0235 \\
(0.0143)\end{array}$ \\
\hline $\operatorname{ROA}(t+1)$ & $\begin{array}{c}0.856 \\
(0.756)\end{array}$ & $\begin{array}{l}10.76^{* * *} \\
(2.422)\end{array}$ & $\begin{array}{c}0.0285 \\
(0.0252)\end{array}$ \\
\hline
\end{tabular}


Table 2. Cont.

\begin{tabular}{|c|c|c|c|}
\hline Variables & Environmental Performance & Sustainable Performance & $\begin{array}{l}\text { Environmental Information } \\
\text { Disclosure (EID) }\end{array}$ \\
\hline Size-Total Assets $(t+1)$ & $\begin{array}{l}-0.568^{* * *} \\
(0.0894)\end{array}$ & $\begin{array}{l}-0.376 \\
(0.275)\end{array}$ & $\begin{array}{l}-0.0189 * * * \\
(0.00298)\end{array}$ \\
\hline \multicolumn{4}{|c|}{$\begin{array}{l}\text { Notes: } 1 \text {. Where ***,**, and * show the significance levels at } p<0.01, p<0.05 \text {, and } p<0.1 \text {, respectively. } 2 \text {. Parentheses show the robust } \\
\text { standard errors. } 3 \text {. The following equation was used to test the exogeneity: } S E A_{i t}=B C_{i t} \beta_{B C}+C_{i t} \beta_{C}+Z_{i t} \beta_{Z}+X_{i t} \partial+W_{i(t-1)} \delta+\epsilon_{i}+\epsilon_{i t} \\
\text { (Equation (4)), where } W_{i(t-1)} \text { is a vector containing the one-period lead values of BC and the elements of the C, Z, and X vectors (or of a } \\
\text { subset thereof). Strict exogeneity of any } W_{i} \text { requires that } \delta_{i}=0 \text {. }\end{array}$} \\
\hline & \multicolumn{3}{|c|}{$\begin{array}{l}\text { The values of the exogeneity tes } \\
\text { across all measures there is evidence } \\
\text { meetings were not strictly exogenous } \\
\text { to assets, ROA, and size were not stri } \\
\text { dependent variables. For all other vari } \\
\text { be rejected. }\end{array}$} \\
\hline \multicolumn{4}{|c|}{ 4.1. System GMM Parameter Estimates } \\
\hline \multicolumn{4}{|c|}{$\begin{array}{l}\text { Table } 3 \text { reports the System GMM parameter estimates along with all relevant diagnos- } \\
\text { tic tests and } p \text {-values. Columns } 2,3 \text {, and } 4 \text { provide the results of board composition impact } \\
\text { on environmental performance, sustainable performance, and EID, respectively. }\end{array}$} \\
\hline Variables & Environmental Performance & Sustainable Performance & $\begin{array}{c}\text { Environmental Information } \\
\text { Disclosure }\end{array}$ \\
\hline & $0.164^{* * *}$ & $0.513^{* * *}$ & $0.00547^{* * *}$ \\
\hline Board Size & $(0.0241)$ & $(0.0691)$ & $(0.000802)$ \\
\hline Board Independence & $\begin{array}{l}2.816^{* * *} \\
(0.746)\end{array}$ & $\begin{array}{l}8.607 * * * \\
(2.145)\end{array}$ & $\begin{array}{l}0.0939 * * * \\
(0.0249)\end{array}$ \\
\hline & $-2.384 * * *$ & $-2.620^{* * * *}$ & $-0.0795^{* * *}$ \\
\hline Board Gender Diversity & $(0.320)$ & $(0.917)$ & (0.0107) \\
\hline & -0.129 & $-0.433 *$ & -0.00430 \\
\hline CEO Duality & $(0.0788)$ & $(0.226)$ & $(0.00263)$ \\
\hline & $-0.0334^{* * *}$ & $-0.0710^{* * *}$ & $-0.00111^{* * *}$ \\
\hline Board Meetings & $(0.00911)$ & $(0.0262)$ & $(0.000304)$ \\
\hline & -0.0592 & 0.0491 & -0.00197 \\
\hline CEO Gender & $(0.144)$ & $(0.415)$ & $(0.00481)$ \\
\hline CEO Retiring & -0.258 & -0.998 & -0.00861 \\
\hline CEU Retiring & $(0.232)$ & $(0.666)$ & $(0.00773)$ \\
\hline Dol to 1 o & 0.257 & $-1.277^{* *}$ & 0.00858 \\
\hline Debt to Assets & $(0.198)$ & $(0.573)$ & $(0.00660)$ \\
\hline $\mathrm{POA}$ & $1.723^{* * *}$ & $81.72 * * *$ & $0.0574^{* * *}$ \\
\hline RUA & $(0.618)$ & $(1.793)$ & $(0.0206)$ \\
\hline & $0.358^{* * *}$ & $2.106^{* * *}$ & $0.0119^{* * *}$ \\
\hline Size-Total Assets & $(0.0345)$ & $(0.102)$ & $(0.00115)$ \\
\hline & $-8.678^{* * *}$ & $-37.91^{* * *}$ & $-0.289^{* * *}$ \\
\hline Constant & $(0.763)$ & $(2.213)$ & $(0.0254)$ \\
\hline No. of Observations & 14,913 & 14,913 & 14,913 \\
\hline
\end{tabular}


Table 3. Cont.

\begin{tabular}{|c|c|c|c|}
\hline Variables & Environmental Performance & Sustainable Performance & $\begin{array}{c}\text { Environmental Information } \\
\text { Disclosure }\end{array}$ \\
\hline Number of ID & 2838 & 2838 & 2838 \\
\hline \multicolumn{4}{|c|}{ 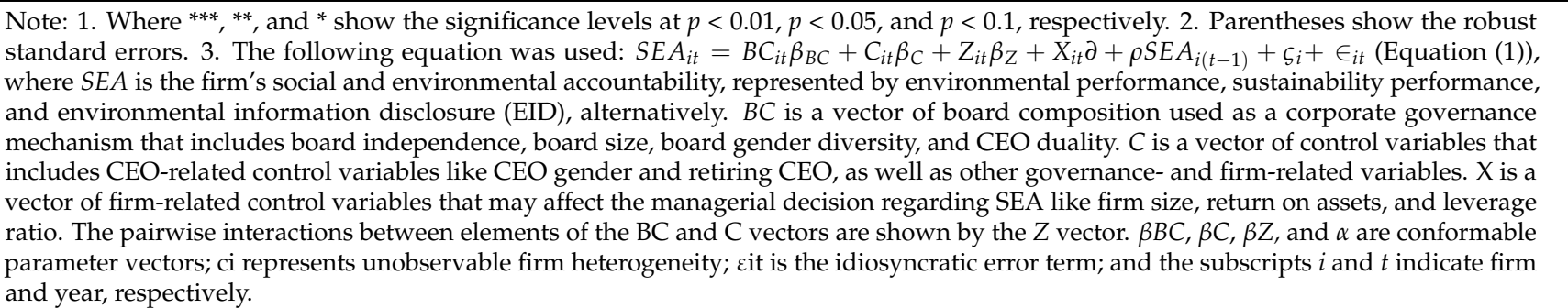 } \\
\hline
\end{tabular}

We found a positive and significant relationship between board size and board independence and all three measures of SEA. Agency theory and stakeholder theory support our findings. Agency theory says that independent directors promote transparency and influence the divulgation of sustainability $[51,88]$. Stakeholder theory also claims that independent directors tend to focus more on stakeholders' interests since they are more responsive to social pressures and therefore motivate businesses more to participate in sustainable development [52]. Our evidence is similarly consistent with the results obtained by Khan et al. [87], who indicated that CSR disclosure is positively affected by board independence in emerging market economies. Our results are also in accordance with earlier research done in developed nations (for instance, [97]), which suggests that independent directors have a beneficial impact on CSR disclosure. In addition, independent managers can pressure companies to take part in CSR disclosure to ensure congruence between the organization's actions and the values of society $[97,98]$. Therefore, our findings imply that board size and independent board directors play an active role in the management monitoring of SEA issues in both emerging and developed markets.

Board gender diversity came out to be negatively and significantly associated with all three measures of accountability. The findings are consistent with Muttakin et al. [71], who found a negative link between female managers and CSR disclosure in emergingmarket countries and identified the following potential causes for this negative relationship: (a) a lack of qualifications and educational experience of female directors, which may negatively affect CSR reporting, and (b) the family ties of directors, who prioritize family interests over sustainability. However, not all aspects of board diversity promoted CSR disclosure for Malaysian companies [99], the reason being the lack of female directors on boards in emerging-market economies $[100,101]$. Most boards in our sample were likely to be controlled by male directors, and so female directors' participation in decisionmaking was limited. Our findings contradict those of studies conducted in industrialized countries $[49,102,103]$. Furthermore, some features of sustainability difficulties in emerging markets may differ from those in developed economies' contexts, norms, and regulations, resulting in this relationship not necessarily presenting a positive sign, as indicated by agency theory and stakeholder theory. According to both views, female directors can promote CSR issues by encouraging companies to provide CSR information.

Finally, the number of board meetings was negatively associated with sustainability performance, environmental performance, and EID. CEO duality was insignificantly related to EID and environmental performance but negatively and significantly related to sustainability performance. Prior studies also concluded that it limits certain governance tasks, such as CSR disclosure (from the stakeholder theory and agency perspective, separation of the roles of chairperson and CEO is preferable) [104,105]. The CEO's dominant position is connected to personal gain rather than sustainable business practices, resulting in less SEA [106]. As a result, CEO dualism can harm SEA, since management, including the CEO, can employ CSR initiatives against the demands and interests of shareholders and stakeholders. These findings hold for other emerging countries; for instance, Malaysian 
companies' CEO duality on boards had a detrimental impact on CSR reporting [105]. The authors believe that if the CEO is also the chairwoman, job duality affects the board's independence, making the directors' monitoring function less effective. Similarly, another study on Chinese companies documented that CEO duality on the boards had a detrimental impact on CSR reporting [107]. The findings are also consistent with those of Uyar [108], who found a negative relationship between CEO dualism and various metrics of accountability. All the indicators of accountability show that $\mathrm{CEO}$ gender and retiring $\mathrm{CEO}$ had no meaningful relationship. In contrast, ROA and size were found to have a substantial positive relationship with all three SEA metrics.

\subsection{Testing the Moderating Effect of CEO Gender on the CG-SEA Nexus}

Table 4 presents the moderating effect of CEO gender on the CG-SEA nexus. For this purpose, we developed the interaction terms of "retiring CEO" and "CEO gender" with each variable of CG. The results shows that the CEO gender had a significant positive moderating effect on all the board characteristics (board size, board independence, board gender diversity, CEO duality) and SEA indicators. Therefore, consistent with prior studies, we conclude that CEO gender positively impacts the CG-SEA nexus. Female CEOs may have a more favorable attitude toward environmental and social issues since they act more sensitively and cooperatively than male ones [62].

Table 4. Moderating effect of CEO gender on the CG-SEA nexus.

\begin{tabular}{|c|c|c|c|}
\hline Variables & Environmental Performance & Sustainable Performance & $\begin{array}{c}\text { Environmental Information } \\
\text { Disclosure }\end{array}$ \\
\hline \multirow[t]{2}{*}{ Board Size } & -0.0540 & -0.186 & -0.00180 \\
\hline & $(0.115)$ & $(0.330)$ & $(0.00383)$ \\
\hline \multirow{2}{*}{ Board Independence } & -3.769 & -11.98 & -0.126 \\
\hline & $(3.101)$ & $(8.912)$ & $(0.103)$ \\
\hline \multirow[t]{2}{*}{ BoardGender Diversity } & 0.180 & 5.321 & 0.00602 \\
\hline & $(1.296)$ & $(3.726)$ & $(0.0432)$ \\
\hline \multirow[t]{2}{*}{ CEO Duality } & -0.351 & -1.093 & -0.0117 \\
\hline & $(0.325)$ & $(0.935)$ & $(0.0108)$ \\
\hline \multirow[t]{2}{*}{ B_Size*CEO_Gend } & $0.226^{*}$ & $0.724^{* *}$ & $0.00753^{*}$ \\
\hline & $(0.117)$ & $(0.337)$ & $(0.00391)$ \\
\hline \multirow[t]{2}{*}{ B_Inde*CEO_Gend } & $6.939 * *$ & $21.75^{* *}$ & $0.231^{* *}$ \\
\hline & $(3.196)$ & $(9.185)$ & $(0.107)$ \\
\hline \multirow[t]{2}{*}{ B_Gend_Div*CEO_Gend } & $-2.716^{* *}$ & $-8.454^{* *}$ & $-0.0905^{* *}$ \\
\hline & $(1.344)$ & $(3.863)$ & $(0.0448)$ \\
\hline \multirow[t]{2}{*}{ Duality ${ }^{*}$ CEO_Gend } & 0.236 & 0.716 & 0.00786 \\
\hline & $(0.335)$ & $(0.962)$ & $(0.0112)$ \\
\hline \multirow[t]{2}{*}{ Board Meetings } & $-0.0334^{* * *}$ & $-0.0708^{* * *}$ & $-0.00111^{* * *}$ \\
\hline & $(0.00911)$ & $(0.0262)$ & $(0.000304)$ \\
\hline \multirow[t]{2}{*}{ CEO Gender } & $-3.903^{* *}$ & $-12.18^{* *}$ & $-0.130^{* *}$ \\
\hline & $(1.989)$ & $(5.718)$ & $(0.0663)$ \\
\hline \multirow[t]{2}{*}{ CEO Retiring } & -0.245 & -0.967 & -0.00817 \\
\hline & $(0.232)$ & $(0.666)$ & $(0.00772)$ \\
\hline \multirow[t]{2}{*}{ Debt to Assets } & 0.253 & $-1.278^{* *}$ & 0.00843 \\
\hline & $(0.198)$ & $(0.574)$ & $(0.00661)$ \\
\hline \multirow[t]{2}{*}{ ROA } & $1.801^{* * *}$ & $81.91^{* * *}$ & $0.0600^{* * *}$ \\
\hline & $(0.618)$ & $(1.793)$ & $(0.0206)$ \\
\hline \multirow[t]{2}{*}{ Size } & $0.356^{* * *}$ & $2.098^{* * * *}$ & $0.0119^{* * *}$ \\
\hline & $(0.0345)$ & $(0.102)$ & $(0.00115)$ \\
\hline \multirow[t]{2}{*}{ Constant } & $-4.968^{* *}$ & $-26.15^{* * *}$ & $-0.166^{* *}$ \\
\hline & $(2.035)$ & $(5.857)$ & $(0.0678)$ \\
\hline Observations & 14,913 & 14,913 & 14,913 \\
\hline Number of ID & 2838 & 2838 & 2838 \\
\hline
\end{tabular}

Note: 1 . Where ${ }^{* * *}, * *$, and ${ }^{*}$ show the significance levels at $p<0.01, p<0.05$, and $p<0.1$, respectively. 2 . Parentheses show the robust standard errors. 3. Moderating variable: CEO gender. 


\section{Conclusions and Policy Implementations}

This study establishes a link between the corporate governance (CG) mechanism with various environmental and social accountability (SEA) measures like sustainability performance, environmental performance, and environmental information disclosures. Moreover, this study found the extent to which various CEO-related attributes moderate the CG-SEA nexus. Using dynamic panel data estimations, we found that board size, independence, and gender diversity in board and CEO duality were all favorably connected to Chinese enterprises' environmental performance. Additionally, our findings imply that the analyzed CEO characteristics positively moderate the relationship between CG and SEA. We hope to add to the existing literature in the following novel ways. First, we evaluated the impact of board compositional characteristics on various accountabilityrelated outcomes, such as environmental performance, sustainability performance, and disclosures. We considered size, independence and gender diversity on the board, and CEO duality as primary determinants in this analysis. Based on agency theory, our findings indicate that these board compositional characteristics are critical in determining the SEA of Chinese enterprises. In general, our findings indicate that all four critical board compositional characteristics (board size, board independence, CEO duality, and board gender diversity) are significantly connected to accountability performance. Thirdly, this is the first study to analyze the unique relationship between China's prevalent corporate governance mechanisms and business accountability while incorporating the mediating roles of CEO attributes. Moreover, this is one of the first studies to analyze Chinese enterprises' sustainable and environmental performance using a dynamic model based on recent and complete panel data. Our results are not prone to endogeneity criticism because we used a dynamic model and a system generalized method of moments technique. Additionally, our study can be utilized to bolster firms' sustainable performance.

The study possesses very strong implications for regulators. The findings may help them to reach the most effective CG mechanism to make firms accountable. Moreover, the findings will guide the kind of CEO attribute that should collaborate with corporate governance mechanisms to make firms accountable to society. These directions will help the Chinese economy to attain a greener GDP. To encourage corporations to be accountable, corporations should develop their corporate governance systems, including improving board gender diversity and independence, maintaining an appropriate board size, and implementing sustainability reporting.

Finally, despite insightful contributions and robust findings, the study possesses some limitations, too. The study was conducted in China, which has a financial system and a corporate governance system that are different from rest of the world due to the unique socialism in the characteristic Chinese economic system. As for what the characteristics of the governance-accountability nexus in other developing and developed countries are, we leave that question for future researchers. Moreover, future research may take insights from upper echelon theory and may study CEO-level attributes as moderators while establishing the relationship between governance and social and environmental accountability.

Author Contributions: Conceptualization, M.K.K. and R.M.A.Z.; Data curation, R.M.A.Z. and A.S.; Formal analysis, M.K.K.; Investigation, M.K.K.; Methodology, M.K.K.; Resources, A.S. and J.S.; Supervision, J.S.; Validation, A.S. and J.S.; Writing-original draft, R.M.A.Z. and M.K.K.; Writingreview \& editing M.K.K. and R.M.A.Z. All authors have read and agreed to the published version of the manuscript.

Funding: This research received no external funding.

Institutional Review Board Statement: Not applicable.

Informed Consent Statement: Not applicable.

Data Availability Statement: Not applicable.

Conflicts of Interest: The authors declare no conflict of interest. 


\section{Appendix A}

Table A1. Descriptive statistics.

\begin{tabular}{|c|c|c|c|c|c|}
\hline Variable & Obs & Mean & Std. Dev. & Min. & Max. \\
\hline Sustainability Performance & 20,643 & 23.331 & 14.961 & -3.82 & 73.31 \\
\hline $\begin{array}{l}\text { Environmental Information } \\
\text { Disclosures (EID) }\end{array}$ & 20,643 & 0.046 & 0.151 & 0 & 0.767 \\
\hline Environmental Performance & 20,643 & 1.391 & 4.537 & 0 & 23 \\
\hline Board Size & 20,651 & 8.569 & 1.699 & 0 & 20 \\
\hline Board Independence & 20,633 & 0.374 & 0.052 & 0.333 & 0.571 \\
\hline CEO Duality & 20,651 & 0.291 & 0.454 & 0 & 1 \\
\hline Number of Board Meeting & 20,651 & 9.611 & 3.941 & 0 & 56 \\
\hline CEO Gender & 20,651 & 0.938 & 0.242 & 0 & 1 \\
\hline Retiring CEO & 20,651 & 0.023 & 0.149 & 0 & 1 \\
\hline CEO Duality & 20,651 & 0.291 & 0.454 & 0 & 1 \\
\hline Debt to Assets Ratio & 20,651 & 0.415 & 0.215 & 0.049 & 0.944 \\
\hline Return on Assets & 20,651 & 0.037 & 0.065 & -0.299 & 0.191 \\
\hline Size (Total Assets) & 20,651 & 21.941 & 1.204 & 19.639 & 25.565 \\
\hline
\end{tabular}

\section{References}

1. Griggs, D.; Stafford-Smith, M.; Gaffney, O.; Rockström, J.; Öhman, M.C.; Shyamsundar, P.; Steffen, W.; Glaser, G.; Kanie, N.; Noble, I. Sustainable development goals for people and planet. Nature 2013, 495, 305-307. [CrossRef] [PubMed]

2. Jain, T.; Jamali, D. Looking inside the black box: The effect of corporate governance on corporate social responsibility. Corp. Gov. Int. Rev. 2016, 24, 253-273. [CrossRef]

3. Chan, M.C.; Watson, J.; Woodliff, D. Corporate governance quality and CSR disclosures. J. Bus. Ethics 2014, 125, 59-73. [CrossRef]

4. Gray, R.; Dey, C.; Owen, D.; Evans, R.; Zadek, S. Struggling with the praxis of social accounting: Stakeholders, accountability, audits and procedures. Account. Audit. Account. J. 1997. [CrossRef]

5. Parker, L.D. Social and environmental accountability research: A view from the commentary box. Account. Audit. Account. J. 2005. [CrossRef]

6. Wang, S.; Li, J.; Zhao, D. Institutional pressures and environmental management practices: The moderating effects of environmental commitment and resource availability. Bus. Strategy Environ. 2018, 27, 52-69. [CrossRef]

7. Wang, L.; Juslin, H. The effects of value on the perception of corporate social responsibility implementation: A study of Chinese youth. Corp. Soc. Responsib. Environ. Manag. 2011, 18, 246-262. [CrossRef]

8. Moon, J.; Shen, X. CSR in China research: Salience, focus and nature. J. Bus. Ethics 2010, 94, 613-629. [CrossRef]

9. Yang, H.H.; Craig, R.; Farley, A. A review of Chinese and English language studies on corporate environmental reporting in China. Crit. Perspect. Account. 2015, 28, 30-48. [CrossRef]

10. Khan, M.K.; He, Y.; Akram, U.; Sarwar, S. Financing and monitoring in an emerging economy: Can investment efficiency be increased? China Econ. Rev. 2017, 45, 62-77. [CrossRef]

11. Ruan, L.; Liu, H. Environmental, Social, Governance Activities and Firm Performance: Evidence from China. Sustainability 2021, 13, 767. [CrossRef]

12. Jizi, M. The influence of board composition on sustainable development disclosure. Bus. Strategy Environ. 2017, 26, 640-655. [CrossRef]

13. Ntim, C.G.; Soobaroyen, T. Black economic empowerment disclosures by South African listed corporations: The influence of ownership and board characteristics. J. Bus. Ethics 2013, 116, 121-138. [CrossRef]

14. Ntim, C.G.; Soobaroyen, T. Corporate governance and performance in socially responsible corporations: New empirical insights from a Neo-Institutional framework. Corp. Gov. Int. Rev. 2013, 21, 468-494. [CrossRef]

15. Nguyen, T.H.; Elmagrhi, M.H.; Ntim, C.G.; Wu, Y. Environmental performance, sustainability, governance and financial performance: Evidence from heavily polluting industries in China. Bus. Strategy Environ. 2021. [CrossRef]

16. Elmagrhi, M.H.; Ntim, C.G.; Elamer, A.A.; Zhang, Q. A study of environmental policies and regulations, governance structures, and environmental performance: The role of female directors. Bus. Strategy Environ. 2019, 28, 206-220. [CrossRef]

17. Shahab, Y.; Ntim, C.G.; Chen, Y.; Ullah, F.; Li, H.X.; Ye, Z. Chief executive officer attributes, sustainable performance, environmental performance, and environmental reporting: New insights from upper echelons perspective. Bus. Strategy Environ. 2020, 29, 1-16. [CrossRef]

18. Lau, C.; Lu, Y.; Liang, Q. Corporate social responsibility in China: A corporate governance approach. J. Bus. Ethics 2016, 136, 73-87. [CrossRef]

19. McGuinness, P.B.; Vieito, J.P.; Wang, M. The role of board gender and foreign ownership in the CSR performance of Chinese listed firms. J. Corp. Financ. 2017, 42, 75-99. [CrossRef] 
20. Noronha, C.; Tou, S.; Cynthia, M.; Guan, J.J. Corporate social responsibility reporting in China: An overview and comparison with major trends. Corp. Soc. Responsib. Environ. Manag. 2013, 20, 29-42. [CrossRef]

21. Rahdari, A.H.; Rostamy, A.A.A. Designing a general set of sustainability indicators at the corporate level. J. Clean. Prod. 2015, 108, 757-771. [CrossRef]

22. Hossain, M.M.; Alam, M.; Hecimovic, A.; Hossain, M.A.; Lema, A.C. Contributing barriers to corporate social and environmental responsibility practices in a developing country: A stakeholder perspective. Sustain. Account. Manag. Policy J. 2016. [CrossRef]

23. Walls, J.L.; Berrone, P.; Phan, P.H. Corporate governance and environmental performance: Is there really a link? Strateg. Manag. J. 2012, 33, 885-913. [CrossRef]

24. Jensen, M.C.; Meckling, W.H. Theory of the firm: Managerial behavior, agency costs and ownership structure. J. Financ. Econ. 1976, 3, 305-360. [CrossRef]

25. Freeman, R.E. Strategic Management: A Stakeholder Approach; Cambridge University Press: Cambridge, UK, 2010.

26. Huang, C.-L.; Kung, F.-H. Drivers of environmental disclosure and stakeholder expectation: Evidence from Taiwan. J. Bus. Ethics 2010, 96, 435-451. [CrossRef]

27. Michelon, G.; Parbonetti, A. The effect of corporate governance on sustainability disclosure. J. Manag. Gov. 2012, 16, 477-509. [CrossRef]

28. Gray, R.; Owen, D.; Adams, C. Some theories for social accounting?: A review essay and a tentative pedagogic categorisation of theorisations around social accounting. Sustain. Environ. Perform. Discl. 2009. [CrossRef]

29. Jamali, D.; Mirshak, R. Corporate social responsibility (CSR): Theory and practice in a developing country context. J. Bus. Ethics 2007, 72, 243-262. [CrossRef]

30. Rao, K.; Tilt, C. Board composition and corporate social responsibility: The role of diversity, gender, strategy and decision making. J. Bus. Ethics 2016, 138, 327-347. [CrossRef]

31. Kiel, G.; Nicholson, G. Boards that Work: A New Guide for Directors; McGraw-Hill Australia: New Yrok, NY, USA, 2003.

32. De Graaf, F.J.; Stoelhorst, J.W. The role of governance in corporate social responsibility: Lessons from Dutch finance. Bus. Soc. 2013, 52, 282-317. [CrossRef]

33. Gallego-Álvarez, I.; Pucheta-Martínez, M.C. Corporate social responsibility reporting and corporate governance mechanisms: An international outlook from emerging countries. Bus. Strategy Dev. 2020, 3, 77-97. [CrossRef]

34. Barnea, A.; Rubin, A. Corporate social responsibility as a conflict between shareholders. J. Bus. Ethics 2010, 97, 71-86. [CrossRef]

35. Cespa, G.; Cestone, G. Corporate social responsibility and managerial entrenchment. J. Econ. Manag. Strategy 2007, 16, 741-771. [CrossRef]

36. Falck, O.; Heblich, S. Corporate social responsibility: Doing well by doing good. Bus. Horiz. 2007, 50, 247-254. [CrossRef]

37. Jensen, M.C. Value maximization, stakeholder theory, and the corporate objective function. J. Appl. Corp. Financ. 2001, 14, 8-21. [CrossRef]

38. Calton, J.M.; Payne, S.L. Coping with paradox: Multistakeholder learning dialogue as a pluralist sensemaking process for addressing messy problems. Bus. Soc. 2003, 42, 7-42. [CrossRef]

39. Scherer, A.G.; Palazzo, G.; Baumann, D. Global rules and private actors: Toward a new role of the transnational corporation in global governance. Bus. Ethics Q. 2006, 16, 505-532. [CrossRef]

40. Jo, H.; Harjoto, M.A. The Causal Effect of Corporate Governance on Corporate Social Responsibility. J. Bus. Ethics 2012, 4, 454-460. [CrossRef]

41. Martins, A.; Gomes, D.; Branco, M.C. Managing corporate social and environmental disclosure: An accountability vs. impression management framework. Sustainability 2021, 13, 296. [CrossRef]

42. Wong, C.W.; Wong, C.Y.; Boon-itt, S.; Tang, A.K. Strategies for Building Environmental Transparency and Accountability. Sustainability 2021, 13, 9116. [CrossRef]

43. Patten, D.M. Exposure, legitimacy, and social disclosure. J. Account. Public Policy 1991, 10, 297-308. [CrossRef]

44. Cho, C.H.; Laine, M.; Roberts, R.W.; Rodrigue, M. The frontstage and backstage of corporate sustainability reporting: Evidence from the Arctic National Wildlife Refuge Bill. J. Bus. Ethics 2018, 152, 865-886. [CrossRef]

45. Yadav, P.L.; Han, S.H.; Rho, J.J. Impact of environmental performance on firm value for sustainable investment: Evidence from large US firms. Bus. Strategy Environ. 2016, 25, 402-420. [CrossRef]

46. Porter, M.; Kramer, M.; Randall-Raconteur, J. 9. So What Now? Harvard Business Review: Boston, MA, USA, 2006.

47. Medina-Salgado, M.S.; Sacristán-Navarro, M.; Guerras-Martín, L.Á. Do Boards of Directors Really Matter in the Cooperation Behavior of Firms? An Exploratory Analysis in Spain. Sustainability 2020, 12, 10114. [CrossRef]

48. Rowe, A.L.; Nowak, M.; Quaddus, M.; Naude, M. Stakeholder engagement and sustainable corporate community investment. Bus. Strategy Environ. 2014, 23, 461-474. [CrossRef]

49. Ben-Amar, W.; McIlkenny, P. Board effectiveness and the voluntary disclosure of climate change information. Bus. Strategy Environ. 2015, 24, 704-719. [CrossRef]

50. Agrawal, A.; Knoeber, C.R. Firm performance and mechanisms to control agency problems between managers and shareholders. J. Financ. Quant. Anal. 1996, 31, 377-397. [CrossRef]

51. Jo, H.; Harjoto, M.A. Corporate governance and firm value: The impact of corporate social responsibility. J. Bus. Ethics 2011, 103, 351-383. [CrossRef] 
52. Ibrahim, N.A.; Angelidis, J.P. The corporate social responsiveness orientation of board members: Are there differences between inside and outside directors? J. Bus. Ethics 1995, 14, 405-410. [CrossRef]

53. Ibrahim, N.A.; Howard, D.P.; Angelidis, J.P. Board members in the service industry: An empirical examination of the relationship between corporate social responsibility orientation and directorial type. J. Bus. Ethics 2003, 47, 393-401. [CrossRef]

54. Herda, D.N.; Taylor, M.E.; Winterbotham, G. The Effect of Board Independence on the Sustainability Reporting Practices of Large US Firms. Soc. Environ. Account. 2012, 6, 178-197.

55. Hussain, N.; Rigoni, U.; Orij, R.P. Corporate governance and sustainability performance: Analysis of triple bottom line performance. J. Bus. Ethics 2018, 149, 411-432. [CrossRef]

56. Chau, G.; Gray, S.J. Family ownership, board independence and voluntary disclosure: Evidence from Hong Kong. J. Int. Account. Audit. Tax. 2010, 19, 93-109. [CrossRef]

57. Donnelly, R.; Mulcahy, M. Board structure, ownership, and voluntary disclosure in Ireland. Corp. Gov. Int. Rev. 2008, 16, 416-429. [CrossRef]

58. Akpan, E.O.; Amran, N.A. Board characteristics and company performance: Evidence from Nigeria. J. Financ. Account. 2014, 2, 81-89. [CrossRef]

59. Galbreath, J. Drivers of corporate social responsibility: The role of formal strategic planning and firm culture. Br. J. Manag. 2010, 21, 511-525. [CrossRef]

60. Gul, F.A.; Srinidhi, B.; Ng, A.C. Does board gender diversity improve the informativeness of stock prices? J. Account. Econ. 2011, 51, 314-338. [CrossRef]

61. Adams, R.B.; Ferreira, D. Women in the boardroom and their impact on governance and performance. J. Financ. Econ. 2009, 94, 291-309. [CrossRef]

62. Kim, H. Glass fence thicker than glass ceiling: The puzzling gaps of women's leadership in Korea. In Culture and Gender in Leadership; Palgrave Macmillan: London, UK, 2013; pp. 253-274.

63. Hillman, A.J.; Cannella, A.A., Jr.; Harris, I.C. Women and racial minorities in the boardroom: How do directors differ? J. Manag. 2002, 28, 747-763. [CrossRef]

64. Harjoto, M.; Laksmana, I.; Lee, R. Board diversity and corporate social responsibility. J. Bus. Ethics 2015, 132, 641-660. [CrossRef]

65. Colaco, H.M.; Myers, P.; Nitkin, M.R. Pathways to leadership: Board independence, diversity and the emerging pipeline in the United States for women directors. Int. J. Discl. Gov. 2011, 8, 122-147. [CrossRef]

66. Bowrin, A.R. Corporate social and environmental reporting in the Caribbean. Soc. Res. J. 2013. [CrossRef]

67. Tamimi, N.; Sebastianelli, R. Transparency among S\&P 500 companies: An analysis of ESG disclosure scores. Manag. Decis. 2017. [CrossRef]

68. Amran, A.; Lee, S.P.; Devi, S.S. The influence of governance structure and strategic corporate social responsibility toward sustainability reporting quality. Bus. Strategy Environ. 2014, 23, 217-235. [CrossRef]

69. Zhang, J.Q.; Zhu, H.; Ding, H.-B. Board composition and corporate social responsibility: An empirical investigation in the post Sarbanes-Oxley era. J. Bus. Ethics 2013, 114, 381-392. [CrossRef]

70. Naveed, K.; Voinea, C.L.; Ali, Z.; Rauf, F.; Fratostiteanu, C. Board Gender Diversity and Corporate Social Performance in Different Industry Groups: Evidence from China. Sustainability 2021, 13, 3142. [CrossRef]

71. Muttakin, M.B.; Khan, A.; Subramaniam, N. Firm characteristics, board diversity and corporate social responsibility: Evidence from Bangladesh. Pac. Account. Rev. 2015. [CrossRef]

72. Liao, L.; Luo, L.; Tang, Q. Gender diversity, board independence, environmental committee and greenhouse gas disclosure. Br. Account. Rev. 2015, 47, 409-424. [CrossRef]

73. Huse, M.; Solberg, A.G. Gender-related boardroom dynamics: How Scandinavian women make and can make contributions on corporate boards. Women Manag. Rev. 2006. [CrossRef]

74. Ahmed, K.; Hossain, M.; Adams, M.B. The effects of board composition and board size on the informativeness of annual accounting earnings. Corp. Gov. Int. Rev. 2006, 14, 418-431. [CrossRef]

75. Dey, A. Corporate governance and agency conflicts. J. Account. Res. 2008, 46, 1143-1181. [CrossRef]

76. Beiner, S.; Drobetz, W.; Schmid, F.; Zimmermann, H. Is board size an independent corporate governance mechanism? Kyklos 2004, 57, 327-356. [CrossRef]

77. Guest, P.M. The impact of board size on firm performance: Evidence from the UK. Eur. J. Financ. 2009, 15, 385-404. [CrossRef]

78. Krishnan, G.; Visvanathan, G. Do auditors price audit committee's expertise? The case of accounting versus nonaccounting financial experts. J. Account. Audit. Financ. 2009, 24, 115-144. [CrossRef]

79. Pathan, S. Strong boards, CEO power and bank risk-taking. J. Bank. Financ. 2009, 33, 1340-1350. [CrossRef]

80. Fama, E.F.; Jensen, M.C. Separation of ownership and control. J. Law Econ. 1983, 26, 301-325. [CrossRef]

81. Dahya, J.; Lonie, A.A.; Power, D. The case for separating the roles of chairman and CEO: An analysis of stock market and accounting data. Corp. Gov. Int. Rev. 1996, 4, 71-77. [CrossRef]

82. Tuggle, C.S.; Sirmon, D.G.; Reutzel, C.R.; Bierman, L. Commanding board of director attention: Investigating how organizational performance and CEO duality affect board members' attention to monitoring. Strateg. Manag. J. 2010, 31, 946-968. [CrossRef]

83. Dias, A.; Lima Rodrigues, L.; Craig, R. Corporate Governance Effects on Social Responsibility Disclosures. Australas. Account. Bus. Financ. J. 2017, 11, 3-22. [CrossRef] 
84. Gul, F.A.; Leung, S. Board leadership, outside directors' expertise and voluntary corporate disclosures. J. Account. Public Policy 2004, 23, 351-379. [CrossRef]

85. Al-Janadi, Y.; Rahman, R.A.; Omar, N.H. Corporate governance mechanisms and voluntary disclosure in Saudi Arabia. Res. J. Financ. Account. 2013, 4, 25-35.

86. Ho, S.S.; Wong, K.S. A study of the relationship between corporate governance structures and the extent of voluntary disclosure. J. Int. Account. Audit. Tax. 2001, 10, 139-156. [CrossRef]

87. Khan, A.; Muttakin, M.B.; Siddiqui, J. Corporate governance and corporate social responsibility disclosures: Evidence from an emerging economy. J. Bus. Ethics 2013, 114, 207-223. [CrossRef]

88. Cheng, E.C.; Courtenay, S.M. Board composition, regulatory regime and voluntary disclosure. Int. J. Account. 2006, 41, 262-289. [CrossRef]

89. Said, R.; Zainuddin, Y.H.; Haron, H. The relationship between corporate social responsibility disclosure and corporate governance characteristics in Malaysian public listed companies. Soc. Responsib. J. 2009. [CrossRef]

90. Haque, F; Ntim, C.G. Environmental policy, sustainable development, governance mechanisms and environmental performance Bus. Strategy Environ. 2018, 27, 415-435. [CrossRef]

91. Arellano, M.; Bover, O. Another look at the instrumental variable estimation of error-components models. J. Econom. 1995, 68, 29-51. [CrossRef]

92. Blundell, R.; Bond, S. Initial conditions and moment restrictions in dynamic panel data models. J. Econom. 1998, 87, 115-143. [CrossRef]

93. Meng, X.H.; Zeng, S.X.; Tam, C.M.; Xu, X.D. Whether top executives' turnover influences environmental responsibility: From the perspective of environmental information disclosure. J. Bus. Ethics 2013, 114, 341-353. [CrossRef]

94. Zeng, S.; Xu, X.; Dong, Z.; Tam, V.W. Towards corporate environmental information disclosure: An empirical study in China. J. Clean. Prod. 2010, 18, 1142-1148. [CrossRef]

95. Cho, C.H.; Patten, D.M. The role of environmental disclosures as tools of legitimacy: A research note. Account. Organ. Soc. 2007, 32, 639-647. [CrossRef]

96. Wooldridge, J.M. Econometric Analysis of Cross Section and Panel Data; MIT press: Cambridge, MA, USA, 2010.

97. Harjoto, M.A.; Jo, H. Corporate governance and CSR nexus. J. Bus. Ethics 2011, 100, 45-67. [CrossRef]

98. Petra, S.T. Do outside independent directors strengthen corporate boards? Corp. Gov. Int. J. Bus. Soc. 2005. [CrossRef]

99. Katmon, N.; Mohamad, Z.Z.; Norwani, N.M.; Al Farooque, O. Comprehensive board diversity and quality of corporate social responsibility disclosure: Evidence from an emerging market. J. Bus. Ethics 2019, 157, 447-481. [CrossRef]

100. Khan, H.U.Z. The effect of corporate governance elements on corporate social responsibility (CSR) reporting: Empirical evidence from private commercial banks of Bangladesh. Int. J. Law Manag. 2010, 52, 82-109. [CrossRef]

101. Akbaş, H.E. The relationship between board characteristics and environmental disclosure: Evidence from Turkish listed companies. South East Eur. J. Econom. Bus. 2016, 11, 7-19. [CrossRef]

102. Frias-Aceituno, J.V.; Rodriguez-Ariza, L.; Garcia-Sanchez, I.M. The role of the board in the dissemination of integrated corporate social reporting. Corp. Soc. Responsib. Environ. Manag. 2013, 20, 219-233. [CrossRef]

103. Fernandez-Feijoo, B.; Romero, S.; Ruiz-Blanco, S. Women on boards: Do they affect sustainability reporting? Corp. Soc. Responsib. Environ. Manag. 2014, 21, 351-364. [CrossRef]

104. Giannarakis, G. The determinants influencing the extent of CSR disclosure. Int. J. Law Manag. 2014. [CrossRef]

105. Sundarasen, S.D.D.; Je-Yen, T.; Rajangam, N. Board composition and corporate social responsibility in an emerging market. Corp. Gov. Int. J. Bus. Soc. 2016. [CrossRef]

106. Mahoney, L.S.; Thorn, L. An examination of the structure of executive compensation and corporate social responsibility: A Canadian investigation. J. Bus. Ethics 2006, 69, 149-162. [CrossRef]

107. Huafang, X.; Jianguo, Y. Ownership structure, board composition and corporate voluntary disclosure: Evidence from listed companies in China. Manag. Audit. J. 2007. [CrossRef]

108. Uyar, A.; Kuzey, C.; Kilic, M.; Karaman, A.S. Board structure, financial performance, corporate social responsibility performance, CSR committee, and CEO duality: Disentangling the connection in healthcare. Corp. Soc. Responsib. Environ. Manag. 2021. [CrossRef] 